\title{
HIGH RATE BIO METHANATION OF MUNICIPAL SOLID WASTE
}

\author{
Upali Wanigartne, Sanja Gunawardena, Kapila Perera \& Ajith De Alwis \\ Department of Chemical and Process Engineering, \\ University of Moratuwa
}

\begin{abstract}
Growing urbanization and industrialization have led to the generation of large quantities of solid wastes, which can be broadly classified as MSW (Municipal Solid Waste) and ISW (Industrial Solid Waste). Among the options available for solid waste management, biomethanation appears to be the most desirable because it is a technology with triple benefits: yields biogas which can replace conventional fuels, provides digested sludge which can be used as a soil conditioner and manages the environment.
\end{abstract}

This work involved the development of a three-stage leachate based bioreactor system for solid waste management. The first stage involves extraction of high organic strength (high in chemical oxygen demand - COD) liquid called leachate from the solids. This stage is known as the hydrolysing stage. Acid formation takes place in the second or the acidification stage in a separate reactor known as the acidification reactor. Biogas is gencrated by treating the acidified leachate in an upflow anacrobic filter (AF) reactor in the third (or the methanation) stage.

Three stage anacrobic systems are increasingly finding its place in biogas gencration. Two kinctically dissimilar groups of bacteria, acetogenes and methogenes are physically separated in acetogenic reactor and methanogenic reactor. This separation allows optimization of both acetogencsis and methanogenesis stages making the process control easicr.

In this method, the organic solid waste is cut into small pieces, fed into the hydrolysing reactor with water and circulated at a fixed rate to wash off organic acids formed until high organic strength is obtained. This is then fed in to the acidification reactor. The acidification phase has retention time of 6 days. Anaerobic conditions prevail inside the reactor during the whole process. The residue left inside from the first reactor is subjected to drying for manure preparation.

The final concentrated leachate obtained after 6 days is fed in to the AF reactor for methanation. This phase has retention time of 5 days. The microbial consortia present in the AF sludge destroys high amount of COD, forming biogas comprising of $65 \%-75 \%$ methane. This system is economically viable, the total space and the time required for the process is low compared to conventional singlephase processes that takes 30-40 days. The system has low water consumption because of the reuse of the AF reactor overflow to the acidification reactor.

Proceedings of the Eighth Annual Forestry and Environment Symposium 2002 of the Department of Forestry and Environmental Science, University of Sri Jayewardenepura, Sri Lanka 